\title{
Development and production of hop in a high temperature region
}

\author{
Desenvolvimento e produção de lúpulo em uma região de alta temperatura \\ Desarrollo y producción de lúpulo en una región de alta temperatura
}

Received: 09/21/2021 | Reviewed: 10/01/2021 | Accept: 10/05/2021| Published: 10/07/2021

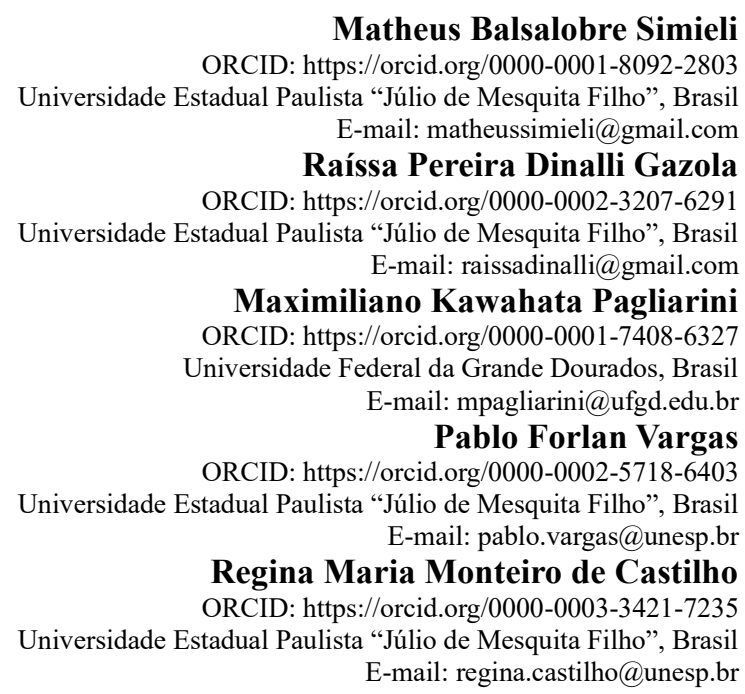

\begin{abstract}
The objective of this work was to evaluate the development and growth of hop cultivars under high temperature conditions. The work was developed at the Farm of Teaching, Research and Extension the School of Engineering of São Paulo State University (UNESP), Campus of Ilha Solteira in two harvests. The design used was randomized blocks with six treatments (cultivars - Cascade, Millenium, Chinook, Centennial, Magnum and Nugget), and six replications. Plant height, leaf chlorophyll index, number of flowers and flower mass in two crops were evaluated. In the first harvest, the Nugget variety had the greatest growth. The Cascade, Millenium and Chinook varieties did not produce flowers. From those that produced, the cultivar Magnum obtained $132.90 \mathrm{~kg}$ ha-1 of flowers. In the second harvest the Cascade and Chinook varieties did not produce flowers. Cultivars Cascade, Millenium, Centennial and Nugget showed the highest growth in height. The Magnum variety produced the greatest amount of flowers (467.33 kg ha-1), followed by the Millenium (290.56 kg ha-1) and Centennial (226.60 kg ha-1) variety. Thus, for the brewing, pharmaceutical or cosmetic industry, the cultivation of the Magnum variety is recommended in the northwest region of São Paulo state, as it produces a greater quantity of flowers. If the purpose is ornamental, the cultivation of the Cascade, Nugget, Centennial and Millenium varieties may be recommended as they show the greatest height development.
\end{abstract}

Keywords: Humulus lupulus L.; Leaf chlorophyll index; Hop varieties.

\section{Resumo}

O objetivo do trabalho foi avaliar o desenvolvimento e crescimento de cultivares de lúpulo em condições de alta temperatura. O trabalho foi desenvolvido na Fazenda de Ensino, Pesquisa e Extensão da Faculdade de Engenharia UNESP, Câmpus de Ilha Solteira em duas safras. O delineamento utilizado foi em blocos casualizados com seis tratamentos (cultivares - Cascade, Millenium, Chinook, Centennial, Magnum e Nugget), e seis repetições. Foram avaliados altura de plantas, índice de clorofila foliar, número de flores e massa de flores mas duas safras. Na primeira safra a variedade Nugget obteve o maior crescimento. As variedades Cascade, Millenium e Chinook não produziram flores. Das que produziram, a cultivar Magnum obteve 132,90 kg ha-1 de flores. Na segunda safra as variedades Cascade e Chinook não produziram flores. As cultivares Cascade, Millenium, Centennial e Nugget apresentaram o maior crescimento em altura. A variedade Magnum foi a que produziu maior quantidade de flores (467,33 kg ha-1), seguida da variedade Millenium (290,56 kg ha-1) e Centennial (226,60 kg ha-1). Dessa forma, para a indústria cervejeira, farmacêutica ou cosmética recomenda-se o cultivo da variedade Magnum na região noroeste do estado de São Paulo por produzir maior quantidade de flores. Caso a finalidade seja ornamental pode-se recomendar o cultivo das variedades Cascade, Nugget, Centennial e Millenium por apresentarem o maior desenvolvimento em altura.

Palavras-chave: Humulus lupulus L.; Índice de clorofila foliar; Variedades de lúpulo. 


\section{Resumen}

El objetivo de este trabajo fue evaluar el desarrollo y crecimiento de cultivares de lúpulo en condiciones de alta temperatura. El trabajo se desarrolló en la Finca de Docencia, Investigación y Extensión de la Facultad de Ingeniería UNESP, Campus Ilha Solteira en dos cosechas. El diseño utilizado fue en bloques al azar con seis tratamientos (cultivares - Cascade, Millenium, Chinook, Centennial, Magnum y Nugget), y seis repeticiones. Se evaluó altura de planta, índice de clorofila foliar, número de flores y masa floral en dos cultivos. En la primera cosecha, la variedad Nugget tuvo el mayor crecimiento. Las variedades Cascade, Millenium y Chinook no produjeron flores. De las que produjeron, el cultivar Magnum obtuvo 132,90 kg ha-1 de flores. En la segunda cosecha las variedades Cascade y Chinook no produjeron flores. Los cultivares Cascade, Millenium, Centennial y Nugget mostraron el mayor crecimiento en altura. La variedad Magnum produjo la mayor cantidad de flores (467,33 kg ha-1), seguida de la variedad Millenium (290,56 kg ha-1) y Centennial (226,60 kg ha-1). Así, para la industria cervecera, farmacéutica o cosmética, se recomienda el cultivo de la variedad Magnum en la región noroeste del estado de São Paulo, ya que produce una mayor cantidad de flores. Si el propósito es ornamental, se puede recomendar el cultivo de las variedades Cascade, Nugget, Centennial y Millenium, ya que presentan el mayor desarrollo en altura.

Palabras clave: Humulus lupulus L.; Índice de clorofila foliar; Variedades de lúpulo.

\section{Introduction}

Brazil has grown in brewing segment due to big manufacturers and in craft brewery sector that constantly appear in the market. It currently ranks third place in the ranking of the largest producers with average of 13 billion litres of beer a year. In 2020, the country reached the mark of 1,2091 registered breweries in 26 Federation Units. The growth of establishments has been constant over the last twenty years, with average growth rate of $19.6 \%$ per year. Recently, this growth rate has increased, being $26.6 \%$ for the last 10 years and $36.4 \%$ for the five past years. Therefore, projecting to future and if the growth rate maintains, in 2025 there will be $36 \%$ more brewery, which will be 7,504 breweries exceeding the number of breweries in the US in the last available balance of 2018 with 7,346 breweries. With an intermediate growth projection, this number would reach close to 5,000 breweries and the most modest at 3,500 (Mapa - Ministério da Agricultura, Pecuária e Abastecimento, 2020a; Cavalcanti et al., 2021).

Water is one of the main ingredients for beer and is then considered to define the locations where the breweries will be installed. The water used to brew beer must be potable and may undergo chemical corrections according to its composition (Mendes Junior \& Barros, 2020). In breweries there is a specific water consumption that varies from 4 to $11 \mathrm{~L}$ per liter of beer produced (Filladeau, et al., 2006).

In addition to water, pure beer consists of malt. Conventionally the most used grain for malting is barley, however other grains such as wheat can be malted and used in beer production (Macleod \& Evans, 2016). Alternatively, wheat is used as part of brewing ingredients, based on similar components of barley (Jin et al., 2018; Trentin et al. 2021).

Last but not least, hops are key ingredient in brewing beer. From the flower or plant strobilus if highlights lupulin, a resin rich in alpha and beta acids, whose functions are to give flavour and beverage aroma (Edwardson, 1952).

Humulus lupulus L., the hop, is a vine, perennial, dioecious, belonging to the Cannabaceae family, originally from temperate regions of the northern hemisphere (Peragine, 2011), which beyond used in brewing production and is used in the production of cosmetics and medicine manufacture.

Hop commercialization is done through pellets, concentrated extract, and fresh cone. The United States are the largest producers with $47 \%$ of world production (48.5 million kg) followed by Germany with 35\% (44 million kg) (Brewers Association, 2019; Economic Commission Summary Reports, 2019).

Brazil does not have production on a commercial scale, with small experimental crops at early stage (Aprolúpulo, 2020). There is no established production chain in the country as it was believed that the crop would not adapt to local climatic conditions (Chagas \& Garcia, 2018). Hops cultivated at latitudes $35^{\circ}$ and $55^{\circ}$ present high vegetative vigour, being largely responsible for an increase in production. However, there are historical records that Santa Catarina and Paraná states were once producers (Silva, 
1958). South Africa, a subtropical country located outside the agroclimatic zoning, produces good quality hops with satisfactory production (Brits, 2008).

According to Brits (2008), to increase hop yields in regions of low latitude and high temperatures, it would be first to provide artificial light (over 15 hours) and the second option would be to select cultivars with a long vegetative period (photoneutral) according to genotypes already cultivated in South Africa. The supply of light increases production costs, therefore, the best alternative is to invest in the improvement of the species.

In Brazil there is no genotype improvement program, the country depending on genetic material imported from other countries. There are about 50 hop cultivars registered in the Ministry of Agriculture, Livestock and Supply, these genotypes mostly of American and German genetic origin, and they are not adapted to Brazilian climatic conditions (Ministério da Agricultura, Pecuária e Abastecimento - Mapa, 2020b).

For this reason, it is of great importance to study the development and production of hop varieties in different regions of the country to identify the best variety for that highlighted region. It is possible to verify that the production of beer in the country is large with a tendency to increase and this implies a greater amount of raw material for production, therefore, we may not be dependent on hops import from other countries. Thus, the objective of this work was to evaluate the development and production of different hop varieties in a region of high temperatures in the north-west region of São Paulo state in Brazil.

\section{Methodology}

The research was performed at Farm of Teaching, Research and Extension the School of Engineering of São Paulo State University (UNESP), Campus of Ilha Solteira, with latitude $20^{\circ} 25^{\mathrm{ec}} \mathrm{S}$, longitude $51^{\circ} 21^{\mathrm{ec}} \mathrm{W}$ and altitude of $330 \mathrm{~m}$, in the municipality of Ilha Solteira, São Paulo state, Brazil, where the soil is classified as sandy-clay Eutrophic RED ARGISSOL (Embrapa, 2013). The evaluations were made in two seasons with two harvests.

Rainfall $(\mathrm{mm})$ and monthly average minimum and maximum temperatures $\left({ }^{\circ} \mathrm{C}\right)$ that comprised the period of the experiment were obtained by the meteorological station of municipality of Ilha Solteira, through the CLIMA channel of UNESP of Ilha Solteira - Hydraulics and Irrigation Area (Unesp - Universidade Estadual Paulista, 2020) and they are demonstrate in table 1.

Table 1. Meteorological data of minimum and maximum temperature and precipitation at municipality of Ilha Solteira, São Paulo state, Brazil.

\begin{tabular}{ccccc}
\hline Month & \multicolumn{3}{c}{ Precipitation $(\mathbf{m m})$} & Mean \\
\cline { 2 - 4 } & Maximum & Minimum & $\begin{array}{c}\text { Average temperature } \\
\left({ }^{\circ} \mathbf{C}\right)\end{array}$ \\
\hline May & 31.0 & 17.3 & 24.1 & 23.7 \\
June & 30.6 & 17.1 & 23.8 & 23.1 \\
July & 31.5 & 16.0 & 23.7 & 23.3 \\
August & 29.8 & 15.5 & 22.6 & 22.0 \\
September & 32.7 & 18.4 & 25.5 & 24.8 \\
October & 33.7 & 21.6 & 27.6 & 26.6 \\
November & 32.3 & 21.7 & 27.0 & 27.1 \\
December & 34.8 & 22.2 & 28.5 & 27.7 \\
\hline
\end{tabular}

Source: Authors based on data collected at Unesp website (Unesp - Universidade Estadual Paulista, 2020).

The beds were prepared to receive the seedlings. Steel pipes of $7 \mathrm{~m}$ long were buried every $3 \mathrm{~m}$, with $2 \mathrm{~m}$ of pipe being below ground and $5 \mathrm{~m}$ above. At the apex of these pipes, a wire was placed that connected all the pipes in which sisal strands 
were strung long enough to reach the surface of the ground. As the hop is a vine, this structure was important for the good development of the plant.

Before planting, soil sampling was performed for fertility analysis, analysed by the Laboratory of Soil Fertility of UNESP/Ilha Solteira, which obtained: P-Resin: $175 \mathrm{mg} \mathrm{dm}^{-3}$; Organic Matter: $19 \mathrm{~g} \mathrm{dm}^{-3}$; $\mathrm{pH}: 5.6$; Potassium: $3.9 \mathrm{mmol}_{\mathrm{c}} \mathrm{dm}^{-3}$; Calcium: $66 \mathrm{mmol}_{\mathrm{c}} \mathrm{dm}^{-3}$; Magnesium: $20 \mathrm{mmol}_{\mathrm{c}} \mathrm{dm}^{-3} ; \mathrm{H}+\mathrm{Al}: 22 \mathrm{mmol}_{\mathrm{c}} \mathrm{dm}^{-3}$; Aluminum: $0 \mathrm{mmol}_{\mathrm{c}} \mathrm{dm}^{-3}$; Cation exchange capacity: $111.9 \mathrm{mmol}_{\mathrm{c}} \mathrm{dm}^{-3}$; base saturation: 80\%; Boron: $0.30 \mathrm{mg} \mathrm{dm}^{-3}$; Copper: $5.3 \mathrm{mg} \mathrm{dm}^{-3}$; Iron: $28 \mathrm{mg} \mathrm{dm}^{-3}$; Manganese: $35.1 \mathrm{mg} \mathrm{dm}^{-3}$ and Zinc: $8.5 \mathrm{mg} \mathrm{dm}^{-3}$.

Organic material produced on Farm was added, which consists of: P-Resin: $24 \mathrm{mg} \mathrm{dm}^{-3}$; Organic Matter: $\mathrm{mg} \mathrm{dm}^{-3} ; \mathrm{pH}$ : 5.0; Potassium: $6.5 \mathrm{mmol}_{\mathrm{c}} \mathrm{dm}^{-3}$; Calcium: $90 \mathrm{mmol}_{\mathrm{c}} \mathrm{dm}^{-3}$; Magnesium: $34 \mathrm{mmol}_{\mathrm{c}} \mathrm{dm}^{-3}$; Aluminum: $1 \mathrm{mmol}_{\mathrm{c}} \mathrm{dm}^{-3}$; Cation exchange capacity: $177.5 \mathrm{mmol}_{\mathrm{c}} \mathrm{dm}^{-3}$; Base saturation: 74\%; Copper: $1.7 \mathrm{mg} \mathrm{dm}^{-3}$; Iron: $86 \mathrm{mg} \mathrm{dm}^{-3}$; Manganese: $56.4 \mathrm{mg} \mathrm{dm}$ ${ }^{3}$ and Zinc: $1.2 \mathrm{mg} \mathrm{dm}^{-3}$.

The plants were obtained by the producer Max Raffaele, which is a hop producer in the municipality of São Paulo, São Paulo State, Brazil, and the seedlings were all the same age. Six hop varieties were tested: Cascade, Millenium, Chinook, Nugget, Magnum and Centennial.

The holes were manually made with depth of $20 \mathrm{~cm}$ and $10 \mathrm{~cm}$ in diameter at a spacing of $1.6 \mathrm{~m}$ between plants and 3.0 $\mathrm{m}$ between rows. The organic compost mentioned above was applied after planting around the seedling.

A drip irrigation system was installed, with a flow of $1.4 \mathrm{~L}$ per plant per day. Weed control was done manually throughout the experiment.

The evaluations were performed in two harvests being: plant height - using a millimetre ruler; leaf chlorophyll index (LCI) - with a Falker brand Chlorophyllometer, model CFL1030, with the leaf analysed being the first of the first third of the plant, in the median region of the laminar of the leaves; number of flowers, fresh mass and dry mass of flowers (g plant-1) - the flowers of each plant were removed and placed in properly identified kraft paper bags, being weighed immediately to determine the fresh mass. Afterwards, they were submitted to seven hours in a forced air circulation oven at $65^{\circ} \mathrm{C}$, weighing again to determine the dry mass.

In the first harvest, plant height evaluations were made at 30, 49, 58, 64, 68 and 74 days after planting (DAP); LCI evaluations at 30, 49 and 81 DAP and flower harvesting at 94 DAP.

After the first harvest, all plants were pruned close to the ground to start the second harvest. Top dressing was performed using 25 g plant-1 of 20-0-20 formulation and and nitrogen supplement was used urea at dose $20 \mathrm{~g}$ plant-1, divided into two parcels, one with $15 \mathrm{~g}$ plant-1 and one with $5 \mathrm{~g}$ plant-1, 15 days after first application.

In the second harvest, plant height evaluations were made at 14, 21, 28, 35 and 44 days after pruning (DAPru); LCI evaluations at 14 and 44 DAPru and flower harvesting at 119 DAPru.

The design used was randomized blocks with six treatments, six replications and six plants per plot, totaling 36 plots. Data were submitted to analysis of variance and in the case of significance at $5 \%$ of probability means were compared by Tukey test by Sisvar computer program (Ferreira, 2019).

\section{Results}

According to Table 2, it is possible to verify that there was statistical difference in all plant height evaluations for hop varieties in the first harvest, and at 30 days after planting (DAP) Centennial, Magnum and Nugget varieties presented the highest averages in relation to Cascade, Millenium and Chinook.

At 49, 58, 64 and 68 DAP; Cascade, Millenium and Chinook continued presenting the lowest height means and from 49 DAP only Nugget have highlighted among all varieties and the difference between this variety and the second biggest in each 
evaluation have increased considerably: at 49 DAP the difference was $31.48 \mathrm{~cm}$ between Nugget (the highest variety) and Magnum (the second biggest variety); at 58 DAP the second biggest variety was Centennial 80.67 cm smaller than Nugget; at 64 DAP and 68 DAP, Nugget and Centennial were the first and the second biggest varieties, however the difference was higher, $130.32 \mathrm{~cm}$ and $157.32 \mathrm{~cm}$, respectively.

Table 2. Height of plants (cm) of different hop varieties at 30, 49, 58, 64 and 68 days after planting (DAP) at first harvest cultivated in the north-west region of São Paulo state, Brazil.

\section{Height of plants (cm)}

Varieties

Days after planting (DAP)

\begin{tabular}{|c|c|c|c|c|c|}
\hline & 30 & 49 & 58 & 64 & 68 \\
\hline Cascade & $10.50 \mathrm{~b}$ & $19.50 \mathrm{c}$ & $24.00 \mathrm{c}$ & $29.00 \mathrm{c}$ & $32.50 \mathrm{c}$ \\
\hline Millenium & $15.75 \mathrm{~b}$ & $21.25 \mathrm{c}$ & $26.75 c$ & $29.75 \mathrm{c}$ & $33.50 \mathrm{c}$ \\
\hline Chinook & $22.68 \mathrm{~b}$ & $26.33 c$ & $26.68 c$ & $29.00 \mathrm{c}$ & $35.68 \mathrm{c}$ \\
\hline Centennial & $46.33 \mathrm{a}$ & $59.10 \mathrm{~b}$ & $102.33 \mathrm{~b}$ & $137.68 \mathrm{~b}$ & $167.68 \mathrm{~b}$ \\
\hline Magnum & $43.33 \mathrm{a}$ & $69.10 \mathrm{~b}$ & $81.33 \mathrm{~b}$ & $105.80 \mathrm{~b}$ & $126.00 \mathrm{~b}$ \\
\hline Nugget & $43.00 \mathrm{a}$ & $100.58 \mathrm{a}$ & $183.00 \mathrm{a}$ & $268.00 \mathrm{a}$ & $325.00 \mathrm{a}$ \\
\hline C.V. $(\%)$ & 24.00 & 12.04 & 27.34 & 28.01 & 24.58 \\
\hline
\end{tabular}

Means followed by the same letter in the column do not differ by Tukey test, at 5\% probability. Source: Authors.

In Table 3 it is possible to verify the leaf chlorophyll index (LCI) of different varieties of hops in days of development. At 30 DAP it may be seen that only Millenium variety differed statistically from Cascade and Chinook varieties. The Millenium presented LCI of 28.08 and the other two of 19.88 and 20.38 respectively.

At 49 DAP, Cascade and Chinook varieties continued to be the ones with the lowest LCI values, however, the one with the highest value, differing statistically from these two, was Magnum variety. Cascade had an LCI of 36.20; Chinook of 35.97 and Magnum of 50.82 .

Table 3. Leaf chlorophyll index (LCI) in plants of different hop varieties at 30 and 49 days after planting (DAP) in the first harvest cultivated in the north-west region of São Paulo state, Brazil.

\begin{tabular}{ccc}
\hline & \multicolumn{2}{c}{ Leaf chlorophyll index (LCI) } \\
\cline { 2 - 3 } Varieties & \multicolumn{3}{c}{ Days after planting (DAP) } \\
\cline { 2 - 3 } & $\mathbf{3 0}$ & $\mathbf{4 9}$ \\
\hline Cascade & $19.88 \mathrm{~b}$ & $36.20 \mathrm{~b}$ \\
Millenium & $28.08 \mathrm{a}$ & $45.28 \mathrm{ab}$ \\
Chinook & $20.38 \mathrm{~b}$ & $35.97 \mathrm{~b}$ \\
Centennial & $24.82 \mathrm{ab}$ & $40.17 \mathrm{ab}$ \\
Magnum & $21.78 \mathrm{ab}$ & $50.82 \mathrm{a}$ \\
Nugget & $23.35 \mathrm{ab}$ & $45.45 \mathrm{ab}$ \\
\hline CV (\%) & 17.80 & 15.86 \\
\hline
\end{tabular}

Means followed by the same letter in the column do not differ by Tukey test, at 5\% probability. Source: Authors. 
Table 4 shows information concerning about number of flowers, fresh and dry mass of flowers for the different hop varieties studied at the end of the first harvest at 94 DAP. The varieties Cascade, Millenium and Chinook after three months of development did not show any flowers. On the other hand, the Magnum variety had the highest number of flowers per plant $(94,25)$ differing statistically from the Centennial (54.50) and Nugget (62.68) variety.

In relation to fresh and dry mass there was no statistical difference between the varieties that produced flowers, however, numerically Magnum variety presented the highest fresh and dry mass in detriment to the others (Table 4).

Table 4. Number of flowers (flowers plant $\left.{ }^{-1}\right)$, fresh and dry mass $\left(\mathrm{g}\right.$ plant $\left.{ }^{-1}\right)$ of flowers of different hop varieties at 94 days after planting (DAP) in the first harvest cultivated in the north-west region of São Paulo state, Brazil.

\begin{tabular}{cccc}
\hline & Number of flowers & Fresh mass & Dry mass \\
\cline { 2 - 4 } Varieties & flowers plant $^{-1}$ & & (g plant $^{-1}$ ) \\
\hline Cascade & $0.00 \mathrm{c}$ & $0.00 \mathrm{~b}$ & $0.00 \mathrm{~b}$ \\
Millenium & $0.00 \mathrm{c}$ & $0.00 \mathrm{~b}$ & $0.00 \mathrm{~b}$ \\
Chinook & $0.00 \mathrm{c}$ & $0.00 \mathrm{~b}$ & $0.00 \mathrm{~b}$ \\
Centennial & $54.50 \mathrm{~b}$ & $40.43 \mathrm{a}$ & $10.63 \mathrm{a}$ \\
Magnum & $94.25 \mathrm{a}$ & $63.79 \mathrm{a}$ & $21.88 \mathrm{a}$ \\
Nugget & $62.68 \mathrm{~b}$ & $50.31 \mathrm{a}$ & $16.87 \mathrm{a}$ \\
\hline CV $(\%)$ & 20.10 & 26.62 & 36.45 \\
\hline
\end{tabular}

Means followed by the same letter in the column do not differ by Tukey test, at $5 \%$ probability. Source: Authors.

After pruning, the evaluation plant height of plant at 14 days (DAPru) (Table 5) shows that the varieties Magnum, Nugget, Millenium and Cascade did not differ statistically from each other, however, the cultivars Magnum and Nugget had a statistically significant difference from the Chinook variety. The latter was the one with the lowest development among all cultivars.

At 21 DAPru, Magnum and Nugget had the highest heights, but they did not differ statistically from each other, but the first variety was the only that showed a statistical difference in relation to the largest number of varieties, four in total (Table 5).

At 28 DAPru, four varieties achieved stability in development and were equal, as they did not show any statistical difference between them, which were Nugget, Centennial, Magnum and Millenium, presented here from the highest to the smallest (Table 5).

In the evaluation of 35 DAPru, there was maintenance of what happened in the previous evaluation, however, at 44 DAPru, only three varieties highlighted, and the order was Nugget $(318.80 \mathrm{~cm})$, Centennial $(295.00 \mathrm{~cm})$ and Millenium $(275.60$ $\mathrm{cm}$ ) (Table 5). In all evaluations, the Chinook variety showed the least development in relation to plant height. 
Table 5. Height of plants (cm) of different hop varieties at 14, 21, 28, 35 and 44 days after pruning (DAPru) at second harvest cultivated in the north-west region of São Paulo state, Brazil.

\begin{tabular}{cccccc}
\hline & \multicolumn{5}{c}{ Height of plants (cm) } \\
\cline { 2 - 6 } Varieties & $\mathbf{1 4}$ & \multicolumn{3}{c}{ Days after pruning (DAPru) } \\
\cline { 2 - 6 } & $\mathbf{1 4}$ & $\mathbf{2 1}$ & $\mathbf{3 5}$ & $\mathbf{4 4}$ \\
\hline Cascade & $22.00 \mathrm{abc}$ & $34.60 \mathrm{~cd}$ & $63.80 \mathrm{~b}$ & $132.00 \mathrm{~b}$ & $354.00 \mathrm{a}$ \\
Millenium & $28.80 \mathrm{abc}$ & $57.60 \mathrm{bc}$ & $136.00 \mathrm{a}$ & $215.60 \mathrm{ab}$ & $275.60 \mathrm{ab}$ \\
Chinook & $7.20 \mathrm{c}$ & $9.40 \mathrm{~d}$ & $13.80 \mathrm{c}$ & $34.00 \mathrm{c}$ & $114.20 \mathrm{c}$ \\
Centennial & $15.80 \mathrm{bc}$ & $62.00 \mathrm{bc}$ & $161.40 \mathrm{a}$ & $250.60 \mathrm{a}$ & $295.00 \mathrm{ab}$ \\
Magnum & $40.00 \mathrm{a}$ & $115.20 \mathrm{a}$ & $140.20 \mathrm{a}$ & $195.80 \mathrm{ab}$ & $248.60 \mathrm{~b}$ \\
Nugget & $35.60 \mathrm{ab}$ & $81.80 \mathrm{ab}$ & $174.40 \mathrm{a}$ & $255.60 \mathrm{a}$ & $318.80 \mathrm{ab}$ \\
\hline C.V.(\%) & 44.85 & 35.26 & 31.33 & 24.68 & 18.38 \\
\hline
\end{tabular}

Means followed by the same letter in the column do not differ by Tukey test, at 5\% probability. Source: Authors.

The LCI shown in Table 6 presented in the first evaluation at 14 DAPru three varieties that stood out with the highest indexes and that did not differ statistically from each other: Nugget (78.32), Magnum (66.43) and Millenium (65.35). At 44 DAPru, however, one more variety was added to the group of those that did not differ and some had their values reduced. The new order was: Magnum (67.87), Centennial (58.12), Millenium (56.25) and Nugget (51.43).

Table 6. Leaf chlorophyll index (LCI) in plants of different hop varieties at 14 and 44 days after pruning (DAPru) in the second harvest cultivated in the north-west region of São Paulo state, Brazil.

\begin{tabular}{ccc}
\hline & \multicolumn{2}{c}{ Leaf chlorophyll index (LCI) } \\
\cline { 2 - 3 } Varieties & \multicolumn{2}{c}{ Days after pruning (DAPru) } \\
\cline { 2 - 3 } & $\mathbf{1 4}$ & $\mathbf{4 4}$ \\
\hline Cascade & $40.80 \mathrm{c}$ & $45.70 \mathrm{~b}$ \\
Millenium & $65.35 \mathrm{ab}$ & $56.25 \mathrm{ab}$ \\
Chinook & $43.07 \mathrm{c}$ & $42.12 \mathrm{~b}$ \\
Centennial & $51.30 \mathrm{bc}$ & $58.12 \mathrm{ab}$ \\
Magnum & $66.43 \mathrm{ab}$ & $67.87 \mathrm{a}$ \\
Nugget & $78.32 \mathrm{a}$ & $51.43 \mathrm{ab}$ \\
\hline CV (\%) & 15.20 & 17.58 \\
\hline
\end{tabular}

Means followed by the same letter in the column do not differ by Tukey test, at $5 \%$ probability. Source: The authors.

At second harvest (119 DAPru) only two varieties did not produce flowers, being Cascade and Chinook (Table 7). The Magnum, Centennial and Millenium varieties did not differ in relation to fresh and dry mass of flowers, however, the Magnum variety differed statistically from the Nugget variety for both fresh and dry mass. In addition, numerically it was the variety that produced the greatest amount of flowers of the five varieties studied (Table 7). 
Table 7. Fresh and dry mass $\left(\mathrm{g}_{\mathrm{g}} \mathrm{plant}^{-1}\right.$ ) of flowers of different hop varieties at 119 days after pruning (DAPru) in the second harvest cultivated in the north-west region of São Paulo state, Brazil.

\begin{tabular}{ccc}
\hline & Fresh mass & Dry mass \\
\cline { 2 - 3 } Varieties & & (g plant $\left.^{-1}\right)$ \\
\hline Cascade & $0.00 \mathrm{c}$ & $0.00 \mathrm{c}$ \\
Millenium & $139.47 \mathrm{ab}$ & $44.10 \mathrm{ab}$ \\
Chinook & $0.00 \mathrm{c}$ & $0.00 \mathrm{c}$ \\
Centennial & $108.77 \mathrm{ab}$ & $46.22 \mathrm{ab}$ \\
Magnum & $224.32 \mathrm{a}$ & $63.58 \mathrm{a}$ \\
Nugget & $29.78 \mathrm{~b}$ & $11.10 \mathrm{~b}$ \\
\hline CV (\%) & 59.30 & 63.26 \\
\hline
\end{tabular}

Means followed by the same letter in the column do not differ by Tukey test, at $5 \%$ probability. Source: The authors.

\section{Discussion}

The growth of hop plants showed different behaviours in both harvests. It is possible to notice that there was faster growth of the plants after drastic pruning, as they took only 14 days (Table 5) to reach almost full height or surpass the height that needed in 30 days (Table 2) when they were planted at the beginning of the experiment. The Cascade variety increased almost 11 times in size in 44 days after pruning compared to 68 days after planting. The Millenium variety increased its size 8 times in the same comparison. The only variety that did not show an expressive difference, there was a decrease, was Nugget, but it maintained the highest plant height of all varieties after 44 days.

The results found may be related to the time needed for seedlings to adapt at new environment, as not all of them are able to accommodate to the new place conditions in the same way and at the same time, and may present morphological changes, such as reducing the width of the leaves to maintain the root development (Téllez et al., 2020).

Berelli et al. (2011) reported that morphological and physiological changes are required in acclimatization period, corroborated by Taiz et al. (2017) who suggest that plants prioritize the formation of new roots in the initial stages of development and Pêgo et al. (2014) indicate that the reduction in the emission of new leaves helps to reduce the mortality rate in seedling transplantation.

Keeping this line of reasoning, it is possible to verify that the leaf chlorophyll index in the first harvest there was significant increase between the evaluations for all varieties (Table 3). At the beginning of development, right after transplanting, plant needs to recover from the stress it suffered to adapt to the new environment, especially in relation to nutrient absorption, as the seedling was stored in a delimited container, moving to a larger environment having to develop its roots for absorption, in this way, the absorbed nutrients are used by the plant where it is most needed.

Among the external factors, $\mathrm{N}$ stands out for being part of the molecular structure of plants and also for acting at some stage of the reactions that lead to the synthesis of chlorophylls, so, even with fertilization, soil correction, in the beginning there will be competition for nutrients within the plant itself (Taiz et al., 2017).

After adaptation, plant metabolism will normalize, and its physiological functions will also be normal. This is interesting to observe after pruning, when the second harvest began.

Even suffering a great stress which was the loss of all its aerial part, as the plant was adapted to the environment with its well-developed root system at 14 DAPru (Table 6) the FCI was already superior to the FCI at 49 DAP (Table 3), in other words, even undergoing pruning, the plant managed to develop in height and in chlorophylls production.

One of the main uses of hops, without a doubt, is for the brewing industry, however, in addition, it is also used in the pharmaceutical, cosmetic and also as an ornamental plant, which is why the purpose of the plant is of great importance at the 
time of choice of variety, especially when it is not known whether the varieties are adapted to the region.

In this case, varieties of this work, in the first harvest, three of them did not produce any flowers, which are Cascade, Millenium and Chinook (Table 4). In the second harvest only Millenium produced flowers, Cascade and Chinook did not adapt to the warm climate of northwestern São Paulo state for flower production. In contrast, Cascade and Millenium developed vegetatively in this second crop producing high plants. In this case, Cascade and Chinook would not be suitable for cultivation if the purpose was to produce hops for brewing but could easily be cultivated for ornamental purposes.

In the system set up in the experiment, extrapolating to hectares, there would be 2,083.33 plants per hectare, as the flowers per plant were weighed, it is possible to calculate the mass of flowers per hectare that each variety produced.

In the first harvest, the production of fresh flowers was lower compared to the second harvest. Magnum produced 132.90 $\mathrm{kg} \mathrm{ha}^{-1}$ of flowers, Nugget $104.81 \mathrm{~kg} \mathrm{ha}^{-1}$ and Centennial produced $84.22 \mathrm{~kg} \mathrm{ha}^{-1}$. In the second harvest, the Nugget variety decreased production to $62.04 \mathrm{~kg} \mathrm{ha}^{-1}$ (reduction of $40.81 \%$ ), while the Centennial variety increased to $226.60 \mathrm{~kg} \mathrm{ha}^{-1}$ (increase of $169 \%$ ), the Millenium variety produced for the first time the amount of $290.56 \mathrm{~kg} \mathrm{ha}^{-1}$ and the Magnum variety increased production to $467.33 \mathrm{~kg} \mathrm{ha}^{-1}$ (increase of $251 \%$ ).

One of the explanations for the non-production of flowers and even for the reduced production of some varieties is there was no dormancy break in which plant naturally must move from the vegetative to the reproductive stage.

Hops perform better, according to Thomé et al. (1999), in areas where the average temperature varies from $15^{\circ} \mathrm{C}$ to 19 ${ }^{\circ} \mathrm{C}$ in summer, $10{ }^{\circ} \mathrm{C}$ in spring and up to $-10^{\circ} \mathrm{C}$ in winter, which does not cause lethal damage to the plant, but it stops growing when it is below $0^{\circ} \mathrm{C}$.

In places with higher hop production, there is a total rainfall (spring and summer) of 300 to $475 \mathrm{~mm}$. Favourable regions for the development of hops would be those where the climate has temperatures like temperate regions, with good rainfall distribution in the vegetative and dry periods during the maturation period; it is recommended that the altitude of the cultivation site be greater than $200 \mathrm{~m}$ (Thomé et al., 1999).

According to Kneen (2003), the crop needs at least 120 days of cold and 15 or more hours of sunshine per day, and to complete its cycle the plant needs 1,800 to 2,000 hours of insolation (Rodrigues et al., 2015).

Despite the region of the study presenting high averages of temperature (Table 1), it was possible to notice that the Magnum variety produced a reasonable amount. It is impossible to make comparisons, since the amount of work on hops is scarce, and each region has its edaphoclimatic characteristics and, therefore, the varieties will behave in different ways.

In 2014, Darby et al. (2014) published an annual report on a hop survey that was already in its fourth year in the United States. The research contained 19 hop materials among which four varieties are in the present work: Cascade, Chinook, Centennial and Nugget. The first two did not produce flowers in this study and were the most productive in the study by Darby and his collaborators, Nugget produced about $600 \mathrm{~kg} \mathrm{ha}^{-1}$ of flowers in the 2014 study, while in the second harvest of the experiment only $62.04 \mathrm{~kg} \mathrm{ha}^{-1}$, while the Centennial variety produced $686.4 \mathrm{~kg} \mathrm{ha}^{-1}$ in the US against $226.60 \mathrm{~kg} \mathrm{ha}^{-1}$ in the northwest of the state of São Paulo. The production of this variety was lower, however, for a region that has no aptitude for the cultivation of hops, being presented for the first time the crop, the production of Millenium, Centennial and mainly Magnum was satisfactory.

\section{Conclusion}

If the purpose of hop cultivation is the brewing, pharmaceutical or cosmetic sector, being flowers the main product, Magnum variety is the most recommended due to the greatest number of fresh flowers produced.

If the purpose of growing hops is ornamental, the use of Cascade, Nugget, Centennial and Millenium varieties may be recommended as these varieties produced the highest plants. 
It is essential that more research be performed with hops in warmer climate regions, mainly aiming the discovery of varieties more adapted to heat conditions and also the useful life of plants after successive harvests and drastic pruning to know the right time to renew the hops planting area.

\section{References}

Aprolúpulo - Associação Brasileira de produtores de lúpulo. (2020). Manual de boas práticas para o cultivo do lúpulo. Retrieved June 8, 2021, from http://aprolupulo.com.br

Berilli, S. D., Carvalho, A. J., Freitas, S. D., Faria, D. C., \& Marinho, C. S. (2011). Avaliação do desenvolvimento de diferentes tamanhos de mudas micropropagadas de abacaxizeiro, após aclimatação. Revista Brasileira de Fruticultura, 33(01), 208-214. https://doi.org/10.1590/S0100-29452011005000018.

Brewers Association. (2019). National Beer Sales \& Production Data. Retrieved June 8, 2021, from https://www.brewersassociation.org/statistics-anddata/national-beer-stats/

Brits, G. (2008). Breeding strategy for the hop industry. George: South African Breweries Hop Farms.

Cavalcanti, R. F. R. de R. M., Silva, J. E. da, \& Fontgalland, I. L. (2021). Custos da água na produção de cerveja: Uma análise econômica comparativa. Research, Society and Development, 2(10), e51710212765. http://dx.doi.org/10.33448/rsd-v10i2.12765

Chagas, E., \& Garcia, L. (2018). Lúpulo em pleno crescimento no Brasil. Revista da Cerveja, 36, 52-56.

Darby, H., Post, J., Calderwood, L., Cummings, E., Lewins, S., Monahan, S., \& Ziegler, S. (2014). Hop Variety Trial: Results from Year Four. Northwest Crops \& Soils Program. 21.

Economic Commission Summary Reports. (2019). International Hop Growers' Convention: Economic Commission - Summary Reports.

Edwardson, J. R. (1952). Hops: Their Botany, History, Production and Utilization. Economic Botany, 6(2), 160-175.

Embrapa - Empresa Brasileira de Pesquisa Agropecuária. (2013). Sistema brasileiro de classificação de solos. Rio de Janeiro: EMBRAPA.

Ferreira, D. F. (2019). Sisvar: a computer analysis system to fixed effects split plot type designs. Revista Brasileira de Biometria, 37(4), 529-535. https://doi.org/10.28951/rbb.v37i4.450.

Fillaudeau, L., Blanpain-Avet, P., \& Daufin, G. (2006). Water, wastewater, and waste management in brewing industries. Journal of Cleaner Production, 14(5), 463-471.

Jin, Z., Zhou, B., Gillespie, J., Gross, T., Barr, J., Simsek, S., \& Schwarz, P. (2018). Production of deoxynivalenol (DON) and DON-3-glucoside during the malting of Fusarium infected hard red spring wheat. Food Control, 85, 6-10.

Kneen, R. (2003). Small scale and organic hops production. British, Columbia.

Macleod, L., \& Evans, E. (2016) Barley: Malting. Encyclopedia of Food Grains, 3(2), 423-433.

Mapa - Ministério da Agricultura, Pecuária e Abastecimento. (2020a). Anuário da Cerveja - 2020. Brasília: MAPA.

Mapa - Ministério da Agricultura, Pecuária e Abastecimento. (2020b). Registro Nacional de Cultivares - RNC. CultivarWeb. Retrieved June 8, 2021, from http://sistemas.agricultura.gov.br/snpc/cultivarweb/cultivares_registradas.php

Mendes Junior, A. A., \& de Barros, Z. X. (2020). Utilização racional de água em cervejaria brasileira. Energia Na Agricultura, 35(2), 287-294. https://doi.org/10.17224/EnergAgric.2020v35n2p287-294

Pêgo, R. G., Paiva, P. D., \& Paiva, R. (2014). Protocolo de micropropagação de Syngonanthus elegans (Bong.) Ruhland: uma espécie ornamental. Acta Scientiarum. Agronomy, 36(3), 347-353.

Peragine, J. (2011). Complete Guide to Growing Your Own Hops, Malts \& Brewing Herbs: Everything You Need to Know Explained Simply. Ocala: Atlantic Publishing Co.

Rodrigues, M. A., Morais, J. S. \& Castro, J. P. M. (2015). Jornadas de lúpulo e cerveja: novas oportunidades de negócio. Instituto Politécnico de Bragança.

Silva, M. A. (1958). Introdução do lúpulo pelo senhor comendador Antônio José Gomes Pereira Bastos. Revista Agrícola do Imperial Instituto Fluminense de Agricultura, 1, 58-69.

Taiz, L., Zeiger, E., Moller, I. M., \& Murphy, A. (2017). Fisiologia e desenvolvimento vegetal. Diversidade vegetal. Porto Alegre: Artmed.

Téllez, H. O., Bomfim, G. V. do, Carvalho, A. C. P. P. de, Azevedo, B. M. de, \& Lozano, C. H. G. (2020). Paclobutrazol no desenvolvimento de mudas de plantas matrizes de abacaxizeiro ornamental. Research, Society and Development, 9(10), e2349108478. https://doi.org/10.33448/rsd-v9i10.8478

Thomé, V. M. R., Zampieri, S., Braga, H. J., Pandolfo, C., Silva Júnior, V. P. da, Bacic, I., Laus Neto, J., Soldateli, D., Gebler, E., ORE, J. D., Echeverria, L., Mattos, M., Suski, P. P. (1999). Zoneamento Agroecológico e Socioeconômico de Santa Catarina. Florianópolis: Epagri. 
Research, Society and Development, v. 10, n. 13, e127101320863, 2021

(CC BY 4.0) | ISSN 2525-3409 | DOI: http://dx.doi.org/10.33448/rsd-v10i13.20863

Trentin, L. S., Raniero, G. Z., Vasques, C. T., Berwig, K. P., Alves, E. da S., Mendes, M. P., \& Monteiro, A. R. G. (2021). Produção de maltes especiais de trigo em escala piloto, produção e caracterização de cerveja. Research, Society and Development, 10(3), e3110312879. https://doi.org/10.33448/rsd-v10i3.12879

Unesp - Universidade Estadual Paulista. (2020). Dados climáticos de Ilha Solteira. Ilha Solteira: Departamento de Fitossanidade, Engenharia Rural e Solos / Área de Hidráulica e Irrigação. Retrieved June 8, 2021, from http://clima.feis.unesp.br/dados_diarios.php 